\title{
Biocalcification by Emiliania huxleyi in batch culture experiments
}

\author{
C. De Bodt, J. Harlay and L. Chou*
}

Laboratoire d'Océanographie Chimique et Géochimie des Eaux, Faculté des Sciences, Université Libre de Bruxelles, Campus de la Plaine - CP 208, B-1050 Brussels, Belgium

\section{ABSTRACT}

Coccolithophores, among which Emiliania huxleyi is the most abundant and widespread species, are considered the most productive calcifying organism on earth. The export of organic carbon and calcification are the main drivers of the biological $\mathrm{CO}_{2}$ pump and are expected to change with oceanic acidification. Coccolithophores are further known to produce transparent exopolymer particles (TEP) that promote particle aggregation. As a result, the TEP and biogenic calcium carbonate $\left(\mathrm{CaCO}_{3}\right)$ contribute to the export of carbon from the surface ocean to deep waters. In this context, we followed the development and the decline of E. huxleyi using batch experiments with monospecific cultures. We studied the link between different processes such as photosynthesis, calcification and the production of TEP. The onset of calcification was delayed in relation to photosynthesis. The timing and the general feature of the dynamics of calcification were closely related to the saturation state of seawater with respect to calcite, $\Omega_{\mathrm{cal}}$. The production of TEP was enhanced after the decline of phytoplankton growth. After nutrient exhaustion, particulate organic carbon (POC) concentration increased linearly with increasing TEP concentration, suggesting that TEP contributes to the POC increase. The production of $\mathrm{CaCO}_{3}$ is also strongly correlated with that of TEP, suggesting that calcification may be considered as a source of TEP precursors.

\section{Introduction}

COCCOLITHOPHORES, especially Emiliania huxleyi, produce large blooms in oceans, in particular at continental margins and shelf seas. They form tests of calcium carbonate platelets (coccoliths) and are major contributors to marine calcification in temperate and subpolar latitudes (Brown and Yoder, 1994). The coccolithophores can cause a draw down of $\mathrm{CO}_{2}$ in the surface ocean, via photosynthesis in the photic zone and vertical export of organic matter to deep waters:

$$
\begin{aligned}
& 106 \mathrm{CO}_{2}+16 \mathrm{NO}_{3}^{-}+\mathrm{H}_{2} \mathrm{PO}_{4}^{-}+17 \mathrm{H}^{+}+ \\
& 122 \mathrm{H}_{2} \mathrm{O} \rightleftharpoons\left(\mathrm{CH}_{2} \mathrm{O}\right)_{106}\left(\mathrm{NH}_{3}\right)_{16} \mathrm{H}_{3} \mathrm{PO}_{4}+138 \mathrm{O}_{2}
\end{aligned}
$$

In contrast, the reaction of calcification is a source of $\mathrm{CO}_{2}$ :

$$
\mathrm{Ca}^{2+}+2 \mathrm{HCO}_{3}^{-} \rightarrow \mathrm{CaCO}_{3}+\mathrm{CO}_{2}+\mathrm{H}_{2} \mathrm{O}
$$

*E-mail: lei.chou@ulb.ac.be

DOI: 10.1180/minmag.2008.072.1.251
Whether the overall process is a net sink or a source of $\mathrm{CO}_{2}$ for the atmosphere depends on the ratio of particulate inorganic carbon (PIC) and organic carbon (POC) produced, the so-called 'rain ratio'. Calcium carbonate may act as ballast due to its large density and this increases the organic carbon flux to the seafloor (Klaas and Archer, 2002). As a result, calcifying organisms could contribute efficiently to the export of organic matter and enhance the oceanic biological pump for the drawdown of atmospheric $\mathrm{CO}_{2}$. Moreover, polysaccharide aggregation, via transparent exopolymer particles (TEP) formation, together with the $\mathrm{CaCO}_{3}$ ballast effect in $E$. huxleyi blooms, have the potential to promote the deep export of carbon on a relatively short time scale (Engel et al., 2004).

The TEP are defined as transparent particles that are formed from acidic polyssacharides and are stainable with Alcian Blue (Passow, 2002). They play an important role in aggregation processes and are formed from phytoplankton excretion products (released as dissolved organic matter 
during the exponential growth or the senescence of phytoplankton bloom) and therefore have a large content of organic carbon (Passow, 2002).

The aim of the batch culture experiments is to study the dynamics of the different processes (growth, calcification and TEP production) following the development and the decline of $E$. huxleyi. To describe the phytoplankton compartment, we followed chlorophyll a, dissolved nutrients (nitrates and phosphates), cell density in addition to POC, particulate nitrogen and TEP. Parameters of the inorganic carbonate system were also monitored to quantify the rate of calcification.

\section{Materials and methods}

\section{Description of the experiment}

Duplicate laboratory batch experiments were conducted on monospecific cultures of $E$. huxleyi (strain AC481 from Normandy, France). The strain was maintained in flasks of $250 \mathrm{ml}$ before starting the experiments. Culture medium consisted of filtered $(0.2 \mu \mathrm{m})$ and autoclaved surface post-bloom seawater sampled in the northern Atlantic ocean $\left(47^{\circ} 45^{\prime} \mathrm{N}, 7^{\circ} 00^{\prime} \mathrm{W}\right)$, enriched with nitrates and phosphates. Cultures were not axenic. Experiments were carried out at an initial $p \mathrm{CO}_{2}$ of $600 \mu \mathrm{atm}$ in an incubator at $13^{\circ} \mathrm{C}$, incident photon flux density was $150 \mu \mathrm{mol}$ $\mathrm{m}^{-2} \mathrm{~s}^{-1}$ and the light/dark cycle was $14 \mathrm{~h} / 10 \mathrm{~h}$. Cultures were carried out in Nalgene polycarbonate carboys $(101)$ filled to 81 . Experiments were monitored for a period of 49 days. Time is referred to as $\mathrm{d}_{x}$ with $x$ as the number of days after strain addition. Samples were taken with a sterile syringe. The $\mathrm{pH}$ was measured on a seawater scale $\left(\mathrm{pH}_{\mathrm{sws}}\right)$ according to Dickson et al. (2007) and the total alkalinity (TA) was determined by the Gran titration method (Gran, 1952); these two parameters allowed the calculation of $\mathrm{pCO}_{2}$ and saturation state with respect to calcite $\left(\Omega_{\text {cal }}\right)$. We also measured chlorophyll a (Chl-a) by fluorimetry, dissolved nutrients $\left(\mathrm{NO}_{3}\right.$ and $\left.\mathrm{PO}_{4}\right)$ by colorimetry, cell density by microscopy, POC and particulate nitrogen ( $\mathrm{PN}$ ) by $\mathrm{CHN}$ analyser, and TEP by colorimetry.

\section{Measurements of calcification}

The TA of the seawater is affected by calcification (or dissolution) because the precipitation (or dissolution) of $1 \mathrm{~mol}$ of $\mathrm{CaCO}_{3}$ reduces (or increases) the TA by 2 molar equivalents (equation 2). Calcium carbonate accumulation and calcification rates were calculated using the alkalinity anomaly technique (Chisholm and Gattuso, 1991). Calcification can be estimated directly from changes in total alkalinity using the relation,

$$
\mathrm{CaCO}_{3} \text { accumulation }=-1 / 2 \times \Delta T A
$$

The TA was corrected for the drawdown of nitrate and phosphate due to photosynthesis (equation 1). When $\Omega_{\text {cal }}$ is far greater than 1, TA consumption by calcification is greater than its release from the dissolution of $\mathrm{CaCO}_{3}$. Thus, $\mathrm{CaCO}_{3}$ accumulation, corresponding to the net concentration, is close to its gross value. On the contrary, when seawater is close to calcite saturation or slightly under-saturated with respect to calcite, dissolution becomes nonnegligible and the variations of TA represent the net result of dissolution and calcification.

Measurement of TEP and estimation of the carbon content of TEP

The TEP concentrations were measured colorimetrically according to Passow and Alldredge (1995). To evaluate the carbon content of TEP (TEP-C), we adopted the following linear relationship used by Engel et al. (2004) to estimate the TEP-C produced during a mesocosm experiment with $E$. huxleyi:

$$
[\mathrm{TEP}-\mathrm{C}]=0.033 \times[\mathrm{TEP}]
$$

where $\left[\right.$ TEP $-\mathrm{C}$ ] is expressed in $\mu \mathrm{mol} 1^{-1}$ and [TEP] in $\mu \mathrm{g} X$ eq. $1^{-1}$.

\section{Results and discussion}

\section{The growth phase of E. huxleyi}

The growth of E. huxleyi led to an increase in Chla concentrations. Its development can be characterized by 4 phases: (1) a lag phase; (2) an exponential growth phase during which cell division occurs under nutrients-replete conditions; (3) a stationary phase where cell division is reduced and nutrients depleted while cells continuously produce large amounts of coccoliths followed by (4) the decline phase (Fig. 1). Growth of E. huxleyi was detected after $\mathrm{d}_{16}$ and induced an increase in Chl-a concentrations up to $28.52 \pm 4.17 \mu \mathrm{g} \mathrm{l}^{-1}$. The $\mathrm{PO}_{4}$ (data not shown) and $\mathrm{NO}_{3}$ (Fig. 1) were consumed during the growth of E. huxleyi. Consumption was slow at the beginning, and became more intense from $d_{20}$ 


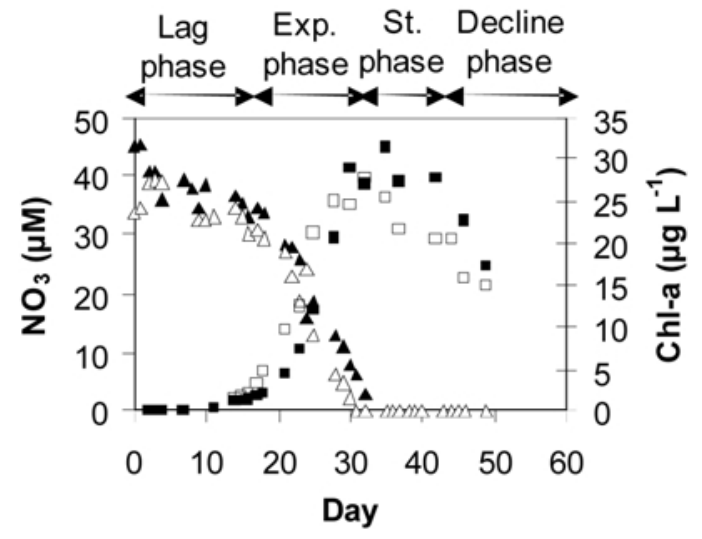

FIG. 1. Evolution of $\mathrm{NO}_{3}$ (triangles) and Chl-a (squares) concentrations during the experiment. Exp. phase = exponential growth phase; and St. phase $=$ stationary phase. Black and open symbols represent results of the duplicate experiments.

until approximately $\mathrm{d}_{30}$, when the nutrient was completely depleted. The onset of the exponential growth phase was concomitant with that of enhanced nutrient consumption. The production of Chl-a stopped when nutrients were depleted (Fig. 1).

POC concentrations increased at the same time as Chl-a but continued to increase after nutrient exhaustion during the stationary and decline phases (data not shown). The largest concentration of POC yielded $8 \mathrm{mg} \mathrm{L}^{-1}$ at the end of the experiment. The PN concentrations also increased at the onset of cell development, but decreased

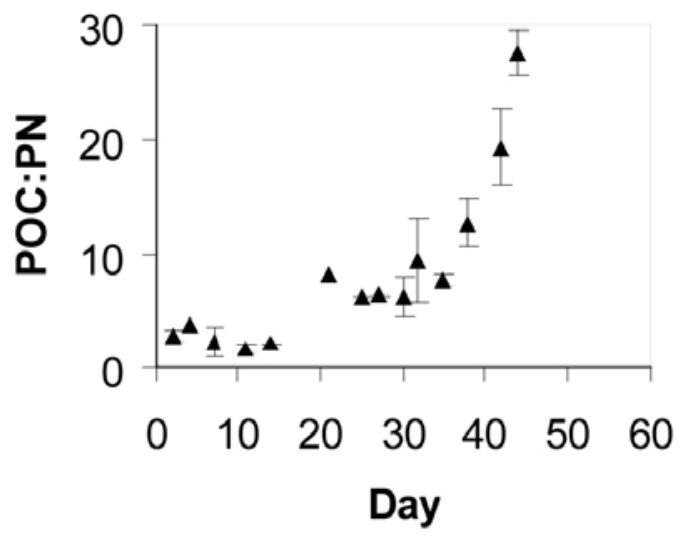

FIG. 2. Evolution of the POC:PN molar ratios (average of the duplicate samples).

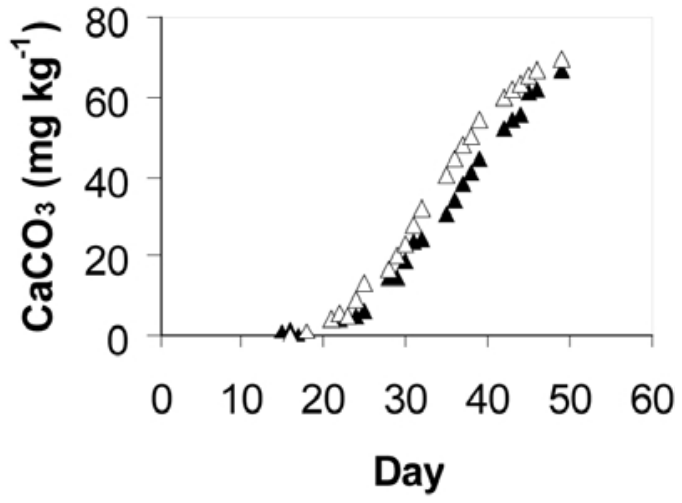

Fig. 3. Net accumulation of calcite during the experiment.

after nutrient depletion, suggesting the remineralization of particulate N. During the exponential growth phase, POC concentrations were closely related to changes in $\mathrm{PN}$, yielding a POC:PN molar ratio close to 6.4 , slightly below the Redfield ratio of 6.6. The POC:PN increased rapidly after nutrient exhaustion until the end of the experiment, indicating the carbon uptake was continuous (Fig. 2). Banse (1994) suggested that when nitrate or phosphate became depleted, photosynthesis would still proceed. This process was termed 'carbon overconsumption' by Toggweiler (1993). A pathway for the excess of DIC uptake by phytoplankton is the release of dissolved organic matter (DOM) followed by the formation of particulate organic carbon (POM) (Schartau et al., 2007). This release of DOM (for example, polysaccharides) leads to the formation

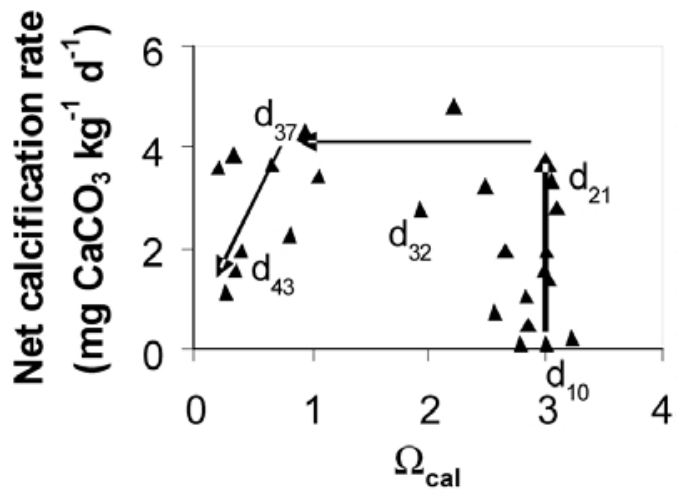

FIG. 4. Evolution of the net calcification rate as a function of $\Omega_{\text {cal }}$ (average of the duplicate sample). Below a $\Omega_{\text {cal }}$ of 1 , the net calcification rate decreased. 

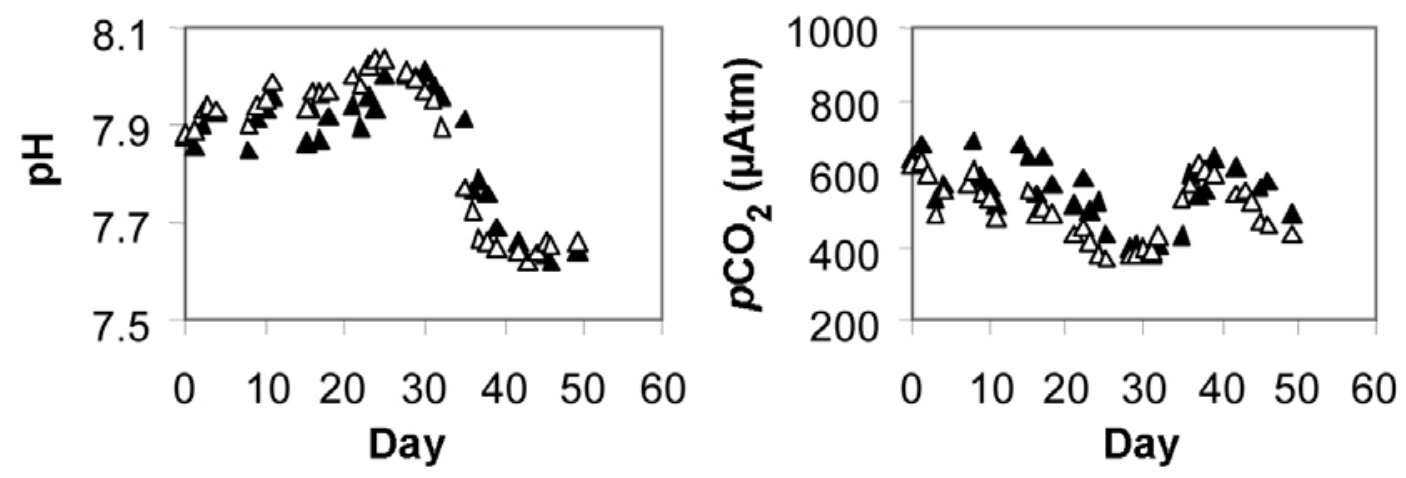

FIG. 5. Evolution of $(a) \mathrm{pH}$; and $(b) \mathrm{pCO}_{2}$ in seawater during the experiment for the duplicate samples.

of larger colloidal particles that will be observed in the TEP formation.

\section{Biocalcification}

The TA was constant at the beginning of the experiment, but decreased sharply from $d_{21}$ (data not shown). The decrease of alkalinity by $1406 \pm 71.1 \mu \mathrm{mol} \mathrm{kg}{ }^{-1}$ corresponds to the precipitation of $67.9 \pm 1.8 \mathrm{mg} \mathrm{kg}^{-1}$ of calcite, according to the TA anomaly calculation (Fig. 3). The consumption of carbonate ions by calcification (equation 2) leads to a decline in $\Omega_{\text {calc }}$ during the experiment, from its initial value $(\sim 3)$ after $\mathrm{d}_{25}$ to $<1$ on $\mathrm{d}_{37}$. The maximum rates of net calcification were observed at a $\Omega_{\text {calc }}$ close to 3 and decreased with decreasing $\Omega_{\text {calc }}$ towards saturation $\left(\Omega_{\text {calc }}=1\right)$ (Fig. 4).

\section{Evolution of $\mathrm{pH}$ and $\mathrm{pCO}$}

The initial $\mathrm{pH}_{\text {SwS }}$ was $7.879 \pm 0.005$. It increased slowly until $\mathrm{d}_{25}$, then decreased until $\mathrm{d}_{40}$ and

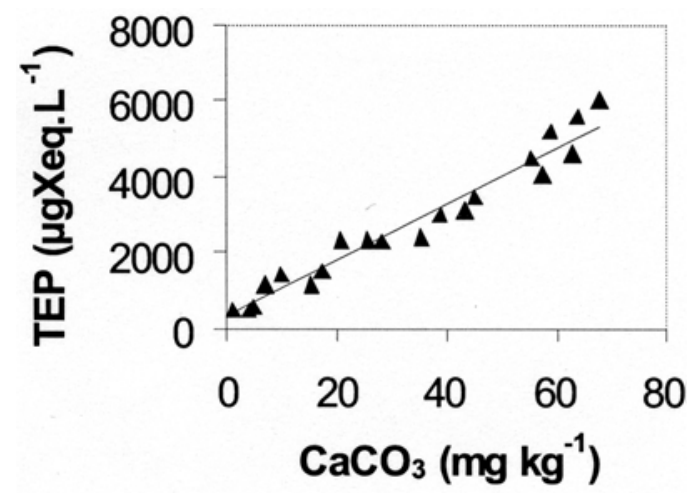

FIG. 6. TEP concentrations as a function of $\mathrm{CaCO}_{3}$ concentrations (average of the duplicate samples). remained constant afterwards (Fig. 5a). The calculated initial $\mathrm{pCO}_{2}$ averaged $627.8 \pm 10.9 \mu \mathrm{Atm}$ and reached a minimum of $385.6 \pm 14.6 \mu \mathrm{Atm}$ before increasing again on $\mathrm{d}_{28}$ to a final $\mathrm{pCO}_{2}$ of $617.4 \pm 27.1 \mu \mathrm{Atm}$ on $\mathrm{d}_{39}$ (Fig. $5 b$ ). The $\mathrm{pCO}_{2}$ decreased again until the end of the experiment. The decrease of $\mathrm{pCO}_{2}$ depends on the buffer capacity of the system but also on the intensity of the biological sink of $\mathrm{CO}_{2}$ (i.e. photosynthesis) during the exponential phase. From $d_{21}$ to $d_{30}$, calcification occurs concomitantly with Chl-a production. At this moment, a part of the $\mathrm{CO}_{2}$ released by calcification could be taken up by photosynthesis. From $\mathrm{d}_{30}$ onward, calcification became the dominant process and the subsequent increase of $\mathrm{pCO}_{2}$, in the second part of the experiment was related to the intense calcification (equation 2). The decrease in $\mathrm{pCO}_{2}$ during the last 10 days of the experiment was related to the decreasing calcification and possibly to the overconsumption of carbon.

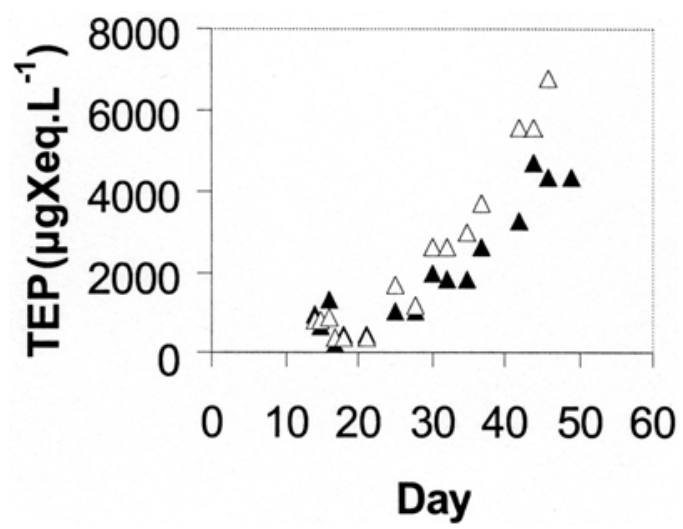

FIG. 7. Evolution of TEP concentrations. 


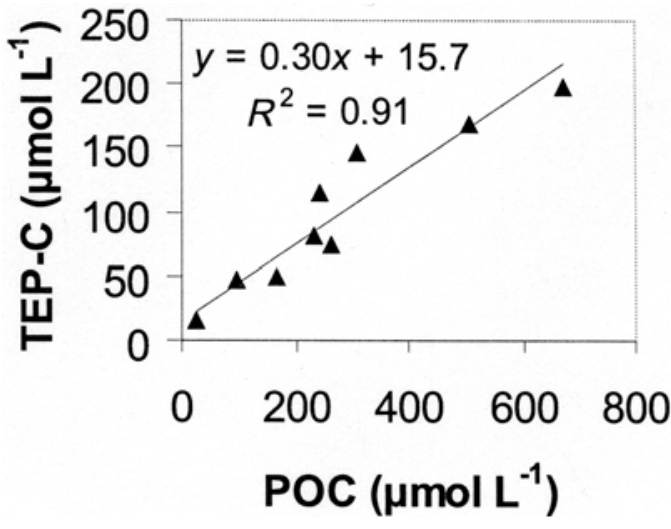

FIG. 8. TEP-C as a function of POC (average of the duplicate samples).

\section{Production of TEP}

\section{Link between TEP and calcification}

By plotting the concentration of TEP against that of $\mathrm{CaCO}_{3}$, we obtained a linear relationship ( $n=21, R^{2}=0.96$, Fig. 6). This suggests that the production of TEP and that of inorganic carbon are closed linked and calcification is a source of TEP precursors.

\section{Evolution of TEP concentration and estimation of the carbon content of TEP (TEP-C)}

The TEP concentration increased rapidly after nutrient decline, reaching a maximum value of $6754 \mu \mathrm{g} \mathrm{X}$ eq. $\mathrm{L}^{-1}$ at the end of the experiment (Fig. 7). The linear relationship between TEP-C and POC ( $n=9, R^{2}=0.91$, Fig. 8) indicates that TEP was responsible for $30 \%$ of the POC increase after nutrient depletion.

\section{Conclusions}

The production of biogenic calcite was detected on $\mathrm{d}_{21}$, five days after the onset of $E$. huxleyi growth, and slowed down on $\mathrm{d}_{43}$. Calcification continued when growth became limited by nutrients. Our results are in accordance with Zondervan et al. (2001), who suggests that coccolith formation is less dependant on $\mathrm{PO}_{4}$ or $\mathrm{NO}_{3}$ than cell division. E. huxleyi could be great producers of TEP that contribute to particle aggregation. Combined with the $\mathrm{CaCO}_{3}$ ballast effect, large-scale coccolithophore blooms have the potential to promote deep export of organic carbon on relatively short time scales.

\section{Acknowledgements}

This work was supported by the EU FP6 IP CarboOcean project (contract no. 511176-2). Additional funding was provided by the Belgian Federal Science Policy Office in the framework of the PEACE project (contract no. SD/CS/03A). This study is a contribution to the EU FP6 European NoE EUR-OCEANS (contract no. 511106-2). It is also a Belgian input to the SOLAS international research initiative.

\section{References}

Banse, K. (1994) Uptake of inorganic carbon and nitrate by marine plankton and the Redfield ratio. Global Biogeochemical Cycles, 8, 81-84.

Brown, C.W. and Yoder, J.A. (1994) Coccolithophorid blooms in the global ocean. Journal of Geophysical Research, 99, 7467-7482.

Chisholm, J.R.M. and Gattuso, J.-P. (1991) Validation of the alkalinity anomaly technique for investigating calcification and photosynthesis in coral reef communities. Limnology and Oceanography, 36, $1232-1239$.

Dickson, A.G., Sabine, C.L. and Christian, J.R. (2007) Guide to best practices for ocean $\mathrm{CO}_{2}$ measurements. PICES Special Publication, 3, 191 pp.

Engel, A., Delille, B., Jacquet, S., Riebesell, U., Rochelle-Newall, E., Terbrüggen, A. and Zondervan, I. (2004) Transparent exopolymer particles and dissolved organic carbon production by Emiliania huxleyi exposed to different $\mathrm{CO}_{2}$ concentrations: a mesocosm experiment. Aquatic Microbial Ecology, 34, 93-104.

Gran, G. (1952) Determination of the equivalence point in potentiometric titrations - Part II. The Analyst, 77, 661-671.

Klaas, C. and Archer, D.E. (2002) Association of sinking organic matter with various types of mineral ballast in the deep sea: Implications for the Rain Ratio. Global Biogeochemical cycles, 16, 63-1-63-14.

Passow, U. (2002) Transparent exopolymer particles (TEP) in aquatic environments. Progress in Oceanography, 55, 287-333.

Passow, U. and Alldredge, A.L. (1995) A dye-binding assay for the spectrophotometric measurement of transparent exopolymer particles (TEP). Limnology and Oceanography, 40, 1326-1335.

Schartau, M., Engel, A., Schröter, J., Thoms, S., Völker, C. and Wolf-Gladrow, D. (2007) Modelling carbon overconsumption and the formation of extracellular particulate organic carbon. Biogeosciences, $\mathbf{4}$, 433-454.

Toggweiler, J. (1993) Carbon overconsumption. Nature, 363, 210-211. 


\section{DE BODT ET AL.}

Van Emburg, P.R., de Jong, E.W. and Daems, W.T. (1986) Immunochemical localization of a polysaccharide from biomineral structures (coccoliths) of Emiliania huxleyi. Journal of Ultrastructure and Molecular Structure Research, 94, 246-259.
Zondervan, I., Zeebe, R.E., Rost, B. and Riebesell, U. (2001) Decreasing marine biogenic calcification: A negative feedback on rising atmospheric $\mathrm{pCO}_{2}$. Global Biogeochemical Cycles, 15, 507-516. 